\title{
Melting My Iron Maiden
}

\author{
T.J. Bryan
}

"Melting My Iron Maiden" nous raconte un fantasme après l'autre. C'est un manifeste multi-narratif qui émane sa propre pratique/attirance/perversion sexuelle et s'en amuse. L'oeuvre de Bryan décrit l'identité politique d'une "lesbienne féministe africaine diasporique" qui brandit un drapeau de fierté et d'inclusion pour une hors-la-loi sexuelle. Elle témoigne de/expose les accessoires du pouvoir et de la colonisation. Elle se bat contre les définitions éphémères et les sentiments évasifs qui collent à la pratique S/M. Elle les travestit, les possède à sa manière avec un spectre de mauvaise conduite qui se transforme en amour, respect et acceptation de soi.

Acceptable (read: no risk involved) scenes of egalitarian, 'womyn loving womyn,' feminist sex just don't do it for me anymore. I mean ... it takes a lot more to push me over the edge. The edge being where I find m'self after a long day of dealing with the reality of life outside my apartment walls. No matter how much I resist, the residue of oppression clings to my soul. Festering. Fuckin' me over from the inside out. The kicker is: I'm not even allowed to scream out my rage and hurt on the sidewalk without little men in white coats wanting to sedate me and carry me away to Tha Clarke. And showing pain, even in front of collectives and community groups, is seen as a sign of weakness - a signal to upwardly-mobile, "political" barracuda sistren and brethren that I'm ripe for the kill....

PRECIOUS IN TORONTO: Blk, 27-year-old dominant sista in search of fierce release ... catharsis. I wanna bottom in safety between tha sheets. U R a sober yet demonic butch/sista whom I will gift with the power of my raw, carnal lust. A daddy who can take me to tha brink \& back, SAFELY. U have enuff strength, intelligence, capacity \& compassion to receive tha personal power I willingly \& TEMPORARILY give up. 
'Til she shows 'erself, I'm finding that obnoxious dyke porn, skanky het porn and boy porn (whiter than white/Black/'coloured' ... it's ALL good!) does my pussy good. Been reading and writing stories like:

junior looks like a dark brown calvin klein poster boy. (sweet thang's daddy delroy goes out of town on business, leavin' junior all alone to fend for himself. of course junior gets up to mischief... with a crew of banji boys from deep scarberia. they drive him out to cherry beach \& take turns fuckin' his ass \& his face with dicks of all shades \& sizes. junior doesn't beg for mercy, though. he just does as he's told. swallowin' their jism when commanded. lyin' on his back, spreadin' his well-muscled cheeks $\mathcal{E}$ relaxin' his hole on demand. what's a 'girl' to do when daddy's not around?

But where do my politics fit? Sometimes I'm not sure they do. Most times I sorta tuck my anal retentive, Black lesbian values out of sight before I lay back to fuck myself. Without self-doubt and self-censorship hanging like twin albatrosses 'round my neck, I'm free to sweat and rock in time to the action on my page. FUCKin' ecstasy.

That is ... 'til I flip back a few pages and start wondering: did the author think about the hordes of non-Black men who could be wankin' their man meat to a feverish frenzy at the thought of a young, Black man/boy getting raped? Well ... unh ... actually ... probably not. Truth is, it was the uneasy tension between these sorts of questions, my values and my desire that made my pussy juice in the first place. The top girl in me reacted to a situation of absolute domination. My submissive to the total power imbalance and loss of control. When I read raunch I damn near soak my panties as my mind absorbs and accepts the violent implications of words on the sticky, wet page.

she, fierce, black, dreadlocked butch goddess with shoulders out tuh here, kicks down my bedroom door E snarls: "down on your knees. now!" whack! she delivers one hard slap to the side-a my face. overwhelmed by her courage \& her strength, $i$ obey. hot tears begin to flow. "think you're a big woman now? don't look at me. eyes down! crawl to tha bed \& spread your fuckin' legs, bitch." $i$ do as she says. remaining on my hands \& knees, $i$ await her bidding. she straddles my body $\mathcal{E} i$ arch my back to receive the warm piss that she showers down on me.

Most times I'm so damn proud of the decisions I make and the company I 
keep that I forget these are dangerous times for wimmin who believe in life after tribadism and IWD. Society's suppressed, conservative swing is mirrored back to me in many wimmin's/lesbian communities. Instead of admitting what they don't know or don't understand, many anti-S/M lesbian feminists are struggling in the grip of some serious erotophobia (scared of the nasty). They hide their fear, confusion and ignorance behind a feminist banner, ostracizing, isolating and back-stabbing sexual outlaws all in the name of tha cause.

\section{WHOSE CAUSE ARE WE SERVIN' WHEN OUR ASSES ARE SO TIGHT WE CAN'T EVEN WORK A BUTT PLUG UP THERE IN CELEBRATION OF OUR LOVE AND OUR LIVES?}

Somewhere along the line, me and your regular, garden variety, birkenstock-wearin,' empty-theory-spewin,' vanilla-fuckin,' granola-chewin' lesbian/feminists parted ways. Though they comprehend the ways that society has sought to control our communities and our bodies, they insist on confusing the pain we've suffered at the hands of our oppressors with the power/aggression/domination dynamic which can be experienced as a healthy part of the erotic. Instead of being a part of the solution, they're fast becoming a part of my problem.

Years ago $i$ told friends' $n$ lovers 'bout my favourite pre-orgasm fantasy - being cut by my fuckmate. havin' her initials etched into my flesh. my girlz responded with fear \& discomfort. they wanted to know if $i$ was going to talk to my therapist about this \& get some support to work it through (read: stop being so fucked up). 'though i took a hint E stopped speakin' 'bout my lust for rough, menacing sex play for a long time, i didn't stop wanting it....

her strong hands roughly caress the smoothness of my piss-wet skin as she corrects my posture. "chin up. cock that back, baby. $i$ already tole you, legs apart. don't fuck wit' me, little girl." she lubes her latex-gloved fist \& then my twat. "yeah ... that's it. relax ... damn! that's my good girl." $i$ smile, happy that my compliance has pleased her.

she fucks me slowly. bending my iron will to hers. enterin' me, one finger at a time 'til her fist fills me. my back supports her sweating, straining weight as her teeth rip into my skin. my pussy tightens around her pumping hand. sweet pain grounds me in my flesh. 
MISCONCEPTION: IF THE SEX WAS GOOD, THERE WOULD BE NO ONE ON TOP OR IN CONTROL. I WOULD BE ABLE TO RELAX, SMILE AND MOAN POLITELY.

SO I COME BACK WITH: CAN'T U SEE THAT MY SLOWLY SIMMERING CASE OF STRONG-BLACK-DYKE-GONNA-TAKE-CARE-A-BUSINESS BURN-OUT IS INTRICATELY LINKED TO IF AND HOW I GET OFF? ${ }^{1}$

Now, I need to add here that there are vibrant and well organized (largely white) S/M organizations and communities in Toronto. But I've had almost no contact with them. Although I've read some leather mags and quite a few S/M anthologies. And 'though I often rummage through downtown stores in search of toys, tools and information, I haven't been to any dungeons, play parties, leather events, workshops or conferences to date. In part this is because I've always had difficulties navigating cliques, dealing with group/mob mentality and deciding if I want to belong or not. But I've also had enough problems validating my status as a novice Player without having to measure my worth with someone else's yardstick too.

there's a leather ball advertised in a queer community rag. $i$ contemplate going, but....

WHEN I'M WRAPPED IN YARD UPON YARD OF COLOURFUL CLOTH, HEAD TIED, ACCESSORISED NOT IN CHROME, LEATHER AND CHAIN, BUT IN COWRIE SHELLS, BEADS AND RAGAMUFFIN GYAL GOLD HOOPS, WILL THEY SEE THA KINK IN ME? EVEN IF I COULD AFFORD THE TICKET, WOULD THEY ALLOW ME INTO THEIR FETE DRESSED AS IS? OR STOP ME AT THE DOOR WITH LECTURES 'BOUT STRICT DRESS CODES AND THE (WHITE) QUEER S/M AESTHETIC? AIN'T MY KWAMINA - THE ESSENTIALIST, WANNABE, CONTINENTAL, AFRICAN QUEEN WEAR THE SORT OF FETISH WEAR THEY HAD IN MIND?

'Til I see leather folk - writers/visionaries - do more examination of whiteness and how/why it dominates information produced and distributed about queer S/M culture. "Til I witness all the self-professed, pierced- 
up, tattoo-covered, scarified, branded, euro 'urban primitives' try and arrive at some clarity 'round issues of racism and cultural appropriation, so as to expand their understanding of Power and consent, this novice bottom won't feel safe enuff to rush naked and vulnerable into their open arms. As I contemplate my emergence into S/M I'm realizing that community is less about finding my place among a group of strangers and more about dedicating myself to seeking out Players who respect the emotional undercurrents of $\mathrm{S} / \mathrm{M}$ and whose race analysis equals the intensity and complexity of their sexual politics.

Right now it's enough for me to know there is a fast-growing group of out, Black, S/M dykes living and playing in T.O. and to have seen a Black dyke reign as Ms. Leather Toronto (you GO girl!). The writings of Donna Barker, Carol Latchford, Sherece Taffe, Jacquie Bishop and Vargus queer, outlaw women of African descent - have helped me navigate and survive in the chasm that separates my BlackNESS from the words of wimmin like Pat Califia, Trish Thomas, Wickie Stamps and Dorothy Allison.

Yeah, my favourite whiter-than-white, kinky, queer sex radicals have expanded my understanding of what a dyke/feminist is and how/who she can fuck. But I've had to move past their experiences, toward an analytical, Black-conscious S/M framework of my own making or risk becoming a caricature of mySELF - a white S/M dyke in black-face. NOT! 'Sides, as Centime ${ }^{2}$ recently reminded me, the Marquis de Sade was just a fucked up white boy with a cruel streak. Girlfriend asked if I really wanted to name what I do after him? I think this Black girl (me) has had it up to HERE with white, upper-class bully boys who don't know their place ... haven't you?

I've GOT a culture, albeit a mix-up/mix-up one. I had an identity, a history and an extended community/family before I began guided exploration of sadism \& masochism/pleasure \& pain/submission \& domination. And though the scenes I've done have been birthed from a place of desire and fantasy, this will never be a racially, culturally or historically neutral place. How could it be when I live in a society steeped in the domination of the powerful over the powerless? Role-play don't mean denial or forgetfulness. My play has GOT to fit into my struggles, with who I am as a Black woman and with where I have been (literally and metaphorically) in the REAL world. 
this flesh was bound for the auction block more than three hundred years before $i$ was even born. but be forewarned: $i^{\prime} m$ not your possession, not your slave. $i$ 'm more than a slut with a big butt who can dance \& fuck better than $i$ can think or feel.

I incorporate a view of race into my sexual politics that goes beyond integrationist and simplistic questions 'bout whether a sista should top or bottom for a white gyal. Or whether there are enuff of US at leather events. Even as I delve into the depths of my own perversion, I hold tight to the memory that Black wimmin, our sexualities and our bodies, have always been seen as deviant. I have met some Black lesbians/wimmin who have chosen to internalize racist views of ourselves by manufacturing asexual, good girl facades that say more about our oppressors than about who we wanna be. I've made a decision to consciously identify, confront, and bust out of the limitations society and community place on my Black, female sexuality.

WATCH this!

Sitting in a white-dominated, queer bar, I inhale the sweet odour of sweat and black leather as a white butch stomps by. Since my common sense is situated much farther north of the wet, hot delta between my thighs and since I'm such a BIG process queen, I take a long look at why my clit's hard. Do I want to trick with this swaggerin', thin-lipped, flatbutt, cock-packin' white gyal? Or am I more attracted to those expensive, black leathers she's wearing and what they signify? And as for her, does she even SEE this big, Black body? And if so, how?

Answers are invoked through the power of my gaze. I scope the room, taking in with a mixture of amusement, pain and anger, white gay and lesbian S/M communities' long-standing love affair with pale/whiteskinned femme(INESS) and obsession/eroticization of BLACK (animal) skin - leather. I look around some more. Silently tallying the number of people in black leather clothing and accessories. Something about this picture makes a lotta sense. Parallels probably as old as the white power structure itself fill my mind. I think about the ways that Black people are often perceived and about society's and MY reading of people IN black leather. Other, outsider, primitive, rebellious, hide your wimmin folk, badbehavin', menacing, sexually aggressive, emotionally unstable, criminal.

Too bad that so many people don't understand that this radical sex business can have as much to do with reinforcing society's racist beliefs 'bout 
dark/Black skin as it does with resistance, queerness, cool wardrobe, and sexual practice. Bizarre irony: people payin' through the nose, hundreds of dollars at a time, for the vicarious experience of risk and persecution wrapped in Black skin/leather while $I$ got the experience of oppression and my gorgeous, chocolate Black (leather) skin for free from my Mummy at birth.

Me and my gorgeous self usually come to this bar face painted, highheeled, dressed to kill, with hair (if I have it) teased to tha max. It's all about drag (AS IN QUEEN) and parody of tha femme(ININE) mystique. I walk arrogantly with the knowledge that my dark, diasporic beauty is light worlds away from the weak, wash' out, goth image so many of the non-Black gyals around me are perpetratin'. Butch/femme gender fuck is fine, but me and most of the Black wimmin I know have been measured (with varying results) against other people's light(er)/white(r), scrawnier, smaller, weaker, wealthier, long/wavy/straight-haired femme(ININE) ideals for eons. This firmly in mind, I do the round-hipped, pert-tittie, garter-belted, femme thang with a conscious twist. Camp it up, work it out, fuck it over, loot it, chew it up, takin' what I want and horkin' up the rest. 'Cuz there's more at stake here than that certain shade of red lipstick, cruisin' daddies or buyin' underwire bras. Femme will always evoke a whole heap of power dynamics straight outta my present and not too distant past. That word wasn't built to hold all of who I am.

IF SOJOURNER TRUTH WAS ALIVE TODAY AND PROCLAIMED HERSELF A LEZZIE AND A FEMME AT THAT, WOULD ANYONE TAKE HER SERIOUSLY? WOULD BUTCHES COME FROM FAR AND WIDE TO GROVEL AT HER FEET AND VIE FOR HER FAVOURS? WOULD SHE BE UNANIMOUSLY VOTED MOST HIGH QUEEN FEMME OF ANY WHITE/OF COLOUR OR EVEN BLACK LESBIAN COMMUNITY?

At the end of tha day, theory and analysis stand side-by-side with endorphin overdrive and feral emotion. All the complicated word-play and insightful critiques pale in the face of me and another soul sista reekin' of leather, sweat and cunt juice, doin' Tha Nasty. O.D.in' on the power of our flesh, soul, will and fury combined. 
her fist explorin' my pussy is the closest i've been to another human being in a very long time. as this realization floods over me, $i$ begin to scream. the toxins i've been carryin' rise to the surface of my skin \& evaporate into the open air like sweat.

my fierce butch growls as $i$ slide my cunt back \& forth 'round her wrist. with her other hand she begins to deliver deliberate, slow, stinging slaps to my ass. moved beyond boundaries, politics $\mathcal{E}$ acceptable feminist behaviour, $i$ cum cussin', drownin' the two of us in a wash of pussy juice, lube \& grateful appreciation.

sniffling, weakened \& for tha time bein' emptied of my pain, i fall asleep wrapped in her loving arms. the next morning strong-black-dyke-gonna-take-care-a-business awakes, leavin' fierce butch to her much-deserved rest. cast iron armour $\mathcal{E}$ arrogant attitude intact, $i$ stand once again ready to take on the whole damn world.

\section{THA CHALLENGE}

THIS HERE'S AN ATTITUDINAL, BLACK CONSCIOUS/BAJANBORN/URBAN/DYKE GYAL CUMIN' AT Y'ALL LIVE FROM THE CROSSROADS OF MANY DIFFERENT REALITIES. IS THERE ROOM IN YOUR COMMUNITY FOR A MULTIFACETED, ABSOLUTELY FABULOUS IRON MAIDEN WHO GETS OFF AND SURVIVES BY MAKIN' LINKS AND PUSHIN' HER OWN LIMITS?

I'M OUT HERE IN LEFT FIELD SEEKIN' WOR(L)DS FILLED WITH MULTIPLICITY/FERTILE WITH POSSIBILITY/ FORMIN' SENTENCES WITH ENUFF EXPLOSIVE POTENTIAL TO PROPEL ME OFF IN SEARCH OF PREVIOUSLY UNKNOWN BORDERLANDS RIPE WITH FUNK/FUELLED BY POTENT RAGE \& THE POWER OF MY PERVERTED/PORNOGRAPHIC/EROTIC/ I WANNA RIDE YOUR ASS THERE/ARE YOU PREPARED TO PRANCE 'N WHINE?/RECEIVIN' THA PAIN, DISPLACEMENT \& ANARCHY THESE WORDS MAY BRING?/DO YOU HAVE THE DISCIPLINE IT'LL TAKE?/CAN YOU OPEN YOURSELF WIDE ENUFF?/STRETCHIN' YOUR CONSCIOUSNESS TO ACCOMMODATE THE IMMENSITY OF MY DEMANDS?/IF YOUR ANSWER'S YES ... ASSUME THA POSITION \& IT WILL BEGIN. 


\section{Notes}

This text was first published by Sister Vision Press in Má-ka Diasporic Juks: Contemporary Writing by Queers of African Descent (1997). Thanx to E. Centime Zeleke, Carol Latchford, Rachel Giese of Xtra, Clare Warner and Sandra Em for their insight and support.

${ }^{1}$ As fate would have it, I managed to locate a mentor in one bad-ass, Black, $\mathrm{S} / \mathrm{M}$ Bulldagger from hell. A lot of the ideas in this piece came out of the time I've spent with her. With much love and respect this unruly Tart In Training (T.I.T.) acknowledges how much she has given me. Much thanx, Daddy Samson. I'm kissing your boots, I'm kissing your boots!

2 E. Centime Zeleke is a feminist, activist, writer and scammer based in Vancouver who describes herself as a Black, Ethiopian femme with an axe. 